\title{
UMA "POSSIBILIDADE IMPOSSÍVEL DE DIZER": O ACONTECIMENTO EM FILOSOFIA E EM LITERATURA, SEGUNDO JACQUES DERRIDA
}

\section{Osvaldo Fontes Filho ${ }^{1}$}

\begin{abstract}
RESUMO: Este artigo focaliza certa "possibilidade impossível de dizer o acontecimento", motivo fértil nos últimos escritos de Derrida. A expressão "a possibilidade do impossível", emprestada do pensamento heideggeriano da Ereignis, concorre a uma ética aporética que repensa as figuras da responsabilidade face à "inapropriabilidade do que acontece". Nos lugares bem conhecidos da lógica derridiana da aporia - a justiça rebelde à regra, o "fantasma do indecidível" em cada acontecimento de decisão, a ilegalidade de toda invenção -, uma ética da alteridade propóe o sujeito apartado dos lugares da adequação a si, ao sabor da interpelação inderivável do acontecer. A dimensão da alteridade de toda decisão solicita a cada situação que se invente "a lei do acontecimento singular", promessa de originalidade. Ora, dizer a "singularidade incalculável e excepcional" do acontecimento é propósito que, para Derrida, somente se justifica como promessa de uma "monolíngua do outro", superfície comunicacional homogênea onde interromper a disseminação. Face às "reservas de indecidível" da ficção, essa promessa de unicidade conhece sua mais evidente impossibilidade, razáo porque este artigo procura, por fim, avaliar a fertilidade desconstrutora da relação testemunho-ficção em literatura, nos momentos em que o pensamento de Derrida rompe com as categorias de verdade, de modo a revelar o literário como o "outro" do filosófico.
\end{abstract}

PALAVRAS-CHAVE: Acontecimento. Filosofia. Literatura. Singularidade. Alteridade. Testemunho. Verdade.

A partir dos anos 1990, assume crescente importância nos textos de Derrida um pensamento do acontecimento. Inicialmente, é a ressonância ética desse pensamento que se deve ressaltar. A questão "o que fazer com o que advém/acontece?” marca os temas da hospitalidade, do dom, do perdão, do segredo, da amizade, do testemunho. Seu reflexo político parece claro: o

1 Professor da Escola de Filosofia, Letras e Ciências Humanas. Departamento de História da Arte. Universidade Federal de São Paulo/UNIFESP. E-mail: osvaldo.fontes@unifesp.br. 
acontecimento, ao fugir dos horizontes transcendentais de calculabilidade, impóe renovado sentimento de uma "desvinculação interruptiva" como condição do vínculo social, sentimento enfim da pervertibilidade das relaçóes. O singular, o único, o imprevisível, o sem regras, ao marcar uma possibilidade aberta ao desenlace de qualquer nó, ao corte ou à interrupção, redefine os termos da decisão responsável. Ao estabelecimento de um poder, de um "eu posso" como possibilidade de neutralização do acaso, vem se substituir o impossível como possibilidade mesma do acontecimento. Derrida assume, pois, a tarefa de opor a uma maquinaria do sujeito

[...] em primeiro lugar tudo o que coloco sob o título de im-possível, do que deve permanecer (de modo náo negativo) estranho à ordem de meus possíveis, à ordem do "eu posso", ou seja, na oposição a todas aquelas convençôes que neutralizam a "acontecimencialidade pura do acontecimento". (DERRIDA, 2003a, p. 123).

A condição de possibilidade paradoxalmente impossibilita o acontecimento, como também a experiência da qual ela se pretende condição. É, antes, o im-possível, enquanto salto para fora dos horizontes de antecipação, que torna possível o acontecer bruto, o advento ou a chegada do outro, do totalmente outro, cuja acolhida Derrida nomeia precisamente: ética.

Im-previsível, im-possível, o acontecimento se demarca por sua alteridade: abissalmente e infinitamente desalojado de todos os seus lugares próprios, da verdade do próprio lugar, do ter-lugar de sua verdade. A eticidade designaria, pois, essa abertura para o risco, para a ameaça do outro. Uma responsabilidade absoluta do outro como resposta à questáo que domina a ética derridiana - o que fazer com o que advém/acontece? - importa, antes de tudo, em um desarmamento, em uma vulnerabilidade, em se deixar expor ao que não se deixa apropriar, ao que nunca advém como oportunidade de uma fiabilidade, de uma fiducialidade - de um programa e de uma prova, da predictividade ou da providência anuladoras do futuro.

Conquanto essa perspectiva esteja permeada pelo particular messianismo de Derrida - ou "messianicidade sem messianismo", isto é, uma abertura para o futuro, para a "vinda do outro como acontecimento da justiça, mas sem horizonte de expectativa e de prefiguração profética” (DERRIDA, 1996b, p. 27) -, não há aqui, propriamente, nenhuma inflação teológica. Há, antes, a inscrição junto à imanência do aqui e agora da irredutível transcendência do acontecimento. A vinda do outro tem lugar junto à imanência; não representa 
um para além, ainda que a título de horizonte teleológico. Ela marca mesmo “[...] certa ausência de horizonte" (DERRIDA, 1996b, p. 15), com o que deixa ver uma "estrutura geral da experiência" - o contar com o melhor, assim como com o pior.

O acontecimento "impossível" é a cada vez a interrupção de uma acolhida, pois é precisamente o que permanece indecidido entre o ter-lugar e o não-lugar; é um surgir indiscernível de seu aparecer, acrescenta-se ao que há; é solicitado que ali se inscreva como suplemento nomeado. Ele próprio é sempre apenas seu próprio desaparecimento. Contudo, uma inscrição pode detê-lo como que no limiar de sua perda. O nome é o que decide o "ter-tido-lugar". Haveria, então, como avaliar uma precisa caracterização da desconstrução: o pensamento como acontecimento, mas anteriormente à sua nomeação, no limite extremo de seu desaparecimento verdadeiro, no desvanecimento de si mesmo, sem a proteção do nome.

A escrita, registro onde se entende esboçar os efeitos de tal caracterização, imitaria o pensamento ainda indecidido. Duplo desafio: pensar e dizer um "resta deixar acontecer". Pensamento e escrita em enfrentamento com a economia aleatória e evanescente do nome. Nos termos de Derrida (2001), o im-possível como o que há de mais "inegavelmente real". Como o Outro. Como a "diferença irredutível não reapropriável do outro".

Situe-se o tema da inapropriabilidade do acontecimento em seus modos de expressão. Infenso a uma narrativa de bom senso, por vezes o acontecimento em Derrida solicita uma linguagem impossível, ilegível. E uma hermenêutica de difícil sustentação. De todo modo, ele exige que sua expressão se faça como um acontecimento na língua dada. Como produção de acontecimentos inauditos. Ora, avaliar o deslocamento conceitual que esses acontecimentos implicam imporia observar a aproximaçáo, que tanto seduz Derrida, entre filosofia e literatura.

Discernir o modo como a literatura é percebida, lida e recebida do ponto de vista da filosofia derridiana parece instrutivo não somente para a própria filosofia - a filosofia oferece sua leitura da literatura? -, mas também porque a literatura permite à filosofia, ao demarcar o que permanece irredutível na ficção, pôr à prova seus modos de pensamento e seus instrumentais 
analíticos. Como manifestamente estes se mostram inoperantes face ao bruto do acontecer, o filósofo encontra no literário oportunidade para suplantar toda restrição metodológica e/ou epistemológica. Pergunte-se, pois: e se a leitura literária de Derrida desse a refletir e a conceber os desvios, deslocamentos, marginalizaçôes, reversôes, dispersôes inerentes a essas duas disciplinas?

É possível circunscrever em Derrida uma inevitável inquietação das partes, quase que um lance de crueldade para com a experiência hermenêutica, como a exigir a apreensão da heteronomia literária como tal, isto é, como $o$ outro de todo discurso do saber. Tal se revela notório em torno do motivo do acontecimento, onde a função referencial da linguagem cede lugar ao trabalho de anomia da "Oni-potência-outra" da ficção, em seu tino de perturbar a articulação do logos como valor de discernibilidade entre o falso e o verdadeiro (DERRIDA, 2005). Abordar a literatura em sua contribuição para uma contrahermenêutica desconstrutivista, na tentativa de fazer ver a inscrição do indizível e do incomensurável, permitiria quiçá reencontrar o efeito próprio às leituras literárias derridianas, qual seja: o discurso filosófico afetado, alterado em sua essência pelos poderes de dramatização da ficção. A literatura como a paixão da filosofia, seu acontecimento (TOUDOIRE-SURLAPIERRE, 2006).

Como inscrever o que se quer irascível a toda conscrição (a todo terlugar) da língua? É notório como a filosofia derridiana parece suspensa à instância de uma apodicidade posta em crise quando da interrogação: "como ler a literatura?" A posiçáo de tal como impóe que se reforce o trabalho junto à linha de riscos traçada pela confrontação nele subjacente.

Reconheça-se, de antemão, na riquíssima semantização poética do pensamento em Derrida, uma consequência da reelaboração das relaçôes entre literatura e filosofia. A desconstrução consiste sempre em fazer mais de um gesto ao mesmo tempo, falar mais de uma língua (ARTOUS-BOUVET, 2006). E, quando é caso do acontecimento, trata-se fundamentalmente de submeter o sentido redutível ao "um" às "reservas de indecidível" da ficção (DERRIDA, 2005, p. 36). Assim, em seu descompromisso para com testemunhos de verdade, a literatura mostra ao filósofo que as palavras possuem poder de especulaçáo e de imaginação e, como tal, deixam o pensamento em seu livre acontecer².

\footnotetext{
${ }^{2}$ Enquanto pensamento do acontecimento, mesmo se esse acontecimento não é mais que... alguns textos, livros, a desconstrução não é redutível a simples itens de uma programação, de uma leitura transversal, prática, calculável. Cumpriria considerar como os motivos derridianos administram sua própria dispersāo exaustiva, como os diferentes phylla da árvore do saber ali se entrelaçam exuberantemente. Se o gesto da desconstrução pode ser dito um "acontecimento" no universo regrado do discurso filosófico (ARTOUS-BOUVET, 2006), isto se dá porque a ficção desvia o conceitual,
} 
Com o que se chega a uma espécie de patamar, ou de nó da questão. Eis, a respeito, um intento de peso: explorar esse lugar intersticial, franja ou margem que, pelo fato mesmo de a linguagem consistir em acontecimento imprevisível, ocupa tanto o filósofo quanto o escritor interessados no inapreensível dos sentidos. Um lugar um tanto inerte, ou neutro, no sentido blanchotiano, para dizer o ter-lugar nos limites do possível.

\section{“O QUE FAZER COM O QUE ACONTECE?”}

A operação elaborada pelo gesto da desconstrução não se confunde simplesmente com uma "teoria" ou mesmo com um "método" de investigação textual. Aspirando a se exercer no espaço prático-político, a questão que ele enuncia é aquela propriamente do acontecimento. $\mathrm{O}$ jogo com o limite que define a escrita derridiana náo seria compreensível sem o motivo do acontecimento, esse inapreensível que desvia ou persiste em resto. Nesse sentido, se há algo a apreender, a reter, no discurso da desconstrução, tal seria justamente o inapreensível. Valeria aqui evocar o imperativo de Glas: "[Ah!] você é inapreensível, [então permaneça] resto". O inapreensível não é um conceito, é um resto, o índice de uma transformação recente ou iminente. Aquilo que sobra de um objeto provoca a escrita, impóe-lhe uma lei de sui generis sustentação. Isso porque não basta declinar os sucessivos atributos fenomênicos de um ser ou de um acontecer na extensão de um corpo textual. Tampouco é suficiente reativálos ao longo de uma contabilidade conceitual, na nomeação de um conteúdo de verdade. Responder à lei da coisa, a seu acontecer jamais disponível como tal, quiçá imponha acompanhar o "cálculo" de uma mimesis sem imitação, sem repetição e sem significação. Herança possível do que é inicialmente um acontecimento, ela somente tem futuro virtual ao sobreviver à assinatura e ao romper com seu signatário suposto responsável.

O acontecimento como acaso, risco, surge em Derrida como fundo perfeitamente opaco, inapropriável, que não pode constituir senão um limite ou uma aporia para toda apropriaçáo responsável. Ele parece mesmo pôr em risco a possibilidade do ser-responsável, porquanto represente não somente aquilo por que não se é responsável, mas também aquilo de que não se poderia

fornece-lhe algumas de suas estratégias "retóricas" e posiçôes argumentativas de base. Assim, o Derrida leitor de Maurice Blanchot (em Demeure) é perfeitamente fiel ao credo desconstrutor, ao suscitar a questáo das virtualidades especulativas da literatura e aquelas imaginativas da filosofia. E, em torno da experiência da morte, o "acontecimento por excelência", ele permite observar os efeitos de verdade de uma transposiçấo ficcional da dialética do impossível e do contingente, do singular e do universal. 
de modo algum se apropriar. Certa "inapropriabilidade do que acontece" engaja um dever-ser propriamente o impróprio, segundo uma lógica da ex-(a) propriação (BORRADORI, 2004).

Esclarecer tal tipo de engajamento - e sua lógica correlata - implica ressaltar o que é da ordem de uma suspensão, de uma iminência de interrupção. É o que Derrida denomina o outro: a revolução, o caos, o novo. O instável, o não-fiável, a "instabilidade do não-fiável" consiste em não consistir, em se subtrair à consistência e à constância, à presença, à permanência ou à substância, à essência ou à existência, bem como a todo conceito de verdade que lhes esteja associado.

Não se impóe, pois, evocar uma estratégia retórica que, ao procurar dizer tal subtração e tal inconsistência, colocar-se-ia sob o pleno domínio de um sujeito. Quando do major event de 11 de setembro, Derrida evoca "[...] certa impossibilidade de dizer o acontecimento" ou, melhor, "[...] certa possibilidade impossível de dizer o acontecimento" (DERRIDA, 2001). Uma lógica "renegociada" do possível - o qualificativo é aqui pertinente, pois diz respeito ao que, a partir de Georges Bataille, Derrida (1967) nomeia como "economia geral", regime de escrita soberana contrário a uma "economia do possível" - indica precisa mudança de perspectiva da teoria, apresentando múltiplas conseqüências para a relação com o conceito e com o texto (e a leitura). Essas consequências, embora bem conhecidas do ponto de vista conceitual referem lugares particularmente paradoxais da ética derridiana tais como o perdão do imperdoável, o dom não-recompensável, a hospitalidade-refém, etc. - , devem ainda ser calculadas ou experimentadas no que comumente se chama teoria da linguagem, para não dizer que se trata de fazer falar uma teoria literária ou, simplesmente, uma teoria do texto.

Razão, pois, para examinar em "Auto-immunités, suicides réels ou symboliques" (DERRIDA, 2004a) o requisitório por uma resposta filosófica à desordem especulativa produzida por um "acontecimento maior". Ali, a análise derridiana do acontecimento como fenômeno de linguagem questiona as sistemáticas de sua nomeação e datação, sua repetição compulsiva através de uma "maquinaria tecnossociopolítica", os múltiplos jogos de sua apropriação a partir de um horizonte de calculabilidade. Como conseqüência, a aporia do acontecimento - seu horizonte de irredutibilidade aos modos de apropriação - passa a solicitar do discurso desconstrutor nova criteriologia para velhas distinçóes: compreender/justificar, impressão/interpretação. Cumpriria, assim, avaliar a solicitação analítica suscitada pela questão: "Qual a natureza 
de um acontecimento que testemunharia, de modo exemplar ou hiperbólico, acerca da essência mesma de um acontecimento" (DERRIDA, 2004a, p. 5)? À evidência, sua capacidade seria a de perturbar o horizonte do conceito ou da essência no qual comumente se reconhece um acontecimento.

Inapreensível, solicitando a palavra, o outro ganha foros de fantasmagoria no momento em que é objetivado como traço do discurso. Dizer o outro é a um só tempo preservá-lo em sua singularidade e impedi-lo de ser o que ele é. Escrever o que acontece fora das condiçôes de possibilidade do sujeito egológico, fora de seus níveis de antecipação, fora de seus horizontes transcendentais de calculabilidade: todo problema da identidade, admita-se, é aqui colocado em jogo, a identidade do sujeito, do texto, de seu valor cultural, a identidade da leitura ou ainda do gênero (literário e/ou filosófico), que fazem dos "protocolos", em vez de estratégias de reapropriação possível, necessárias experiências do impossível.

O “im-possível”, na grafia derridiana, indica o excedente em relação ao horizonte de expectativa do sujeito. Um acontecimento, explica Derrida, não chega nunca "na horizontal", ele não se perfila no horizonte donde se poderia prevê-lo; um acontecimento vem do alto, na vertical, como surpresa absoluta:

$\mathrm{O}$ acontecimento como aquilo que chega é o que verticalmente me cai em cima, sem que eu possa vê-lo vir; o acontecimento náo pode me aparecer antes de chegar senão como impossível. (DERRIDA, 2001, p. 97).

O acontecimento é o que ocorre e, ao ocorrer, acontece de me surpreender, de surpreender e de suspender a compreensão; o acontecimento é de imediato $o$ que náo compreendo. Ou melhor, o acontecimento é de imediato que eu não compreenda. (DERRIDA, 2004b, p. 139).

O im-possível é o sobrevir do acontecimento. Sob a rubrica desse impossível importa, pois, ressaltar certa forma de resistência à domesticação do acontecimento, à circunscrição daquilo que tem lugar. $\mathrm{O}$ problema não é tratado como tal em Derrida, mas se insinua por entre análises específicas relativas à escrita nos variados modos de sua manifestação: poético, filosófico, político etc. Não bastaria, então, salientar o quanto a mimesis em Derrida se reserva o direito de não repetir (uma coisa, um acontecimento, um referente, um significado) e não render dividendos (um sentido ou um significante). Tratar-se-ia aqui não apenas da relação com uma singularidade de impossível reprodução, mas do contornar de uma perda da medida: náo exatamente do 
acontecimento em si - não mais que uma abstração metafísica -, mas da (im) possibilidade do acontecimento.

Invariavelmente, a tarefa é enunciada em Derrida como um empenho junto à língua. Se uma analítica retrógrada do possível suscita somente um "falar ao infinito", sem jamais dar conta do acontecimento na novidade de seu surgimento e na unicidade de sua ocorrência, o estudo sistemático que Derrida propóe da "categoria" ou da "modalidade" do talvez entende abrir para um vocabulário um tanto estranho à filosofia, isto é, à certeza, à verdade, à veracidade. Tantas palavras: o "novo", o "acontecimento", o "vir", a "singularidade", a "primeira vez" impóem uma renovada capacidade de dizer o "talvez", de dizer no "talvez", e de fazer desse dizer um acontecimento.

Há, nisto, uma reivindicação de contemporaneidade. Em Politiques de l'amitié, Derrida se pergunta sobre a possibilidade de dizer nossa pertença a um tempo de mutação, "que é justamente um terrível abalo na estrutura ou na experiência da pertença”. É nesse abalo, insiste Derrida, que ressoam todos os grandes discursos - entenda-se, Bataille, Blanchot, Nancy ou, ainda, Nietzsche - que se rendem à necessidade de refletir e de formalizar "[...] o deslocamento absoluto, o desajuste sem borda" (DERRIDA, 1994, p. 98). Como identificar uma linguagem que opera com "palavras que se consomem numa sombria luz", com sintagmas tão inéditos quanto "relaçôes sem relação", "comunidade sem comunidade", "comunidade impossível”, "X sem X" etc. (DERRIDA, 1994, p. 99)? Toda uma axiomática impossível permanece por ser pensada, no tempo mesmo em que se deslegitima o desejo por uma axiomática. A se repensar, ainda, os recursos de expressão de uma filosofia política confrontada com essas novas aporias, com essa instabilidade semântica, obrigada a ler os possíveis de aparência contraditória sem ceder, complacente, a toda sorte de "realismos".

Procurar dizer o mais bruto, o mais resistente, o mais irredutível, o mais outro de um acontecimento é uma condição tanto de justiça quanto de refinamento crítico. É oportuno, pois, perguntar, com Derrida, pela voz mais convincente e responsável em face da estrutura real do político, das relações de força e de fraqueza, do "nexo social", bem como das marcas e do discurso que o constituem. Eis a indagação com a qual o autor de Politiques de l'amitié nos confronta:

$\mathrm{O}$ que se tornou essa realidade [...] para que seu entendimento pareça o mais conseqüente? Para que se deva assim falar de tal modo? Para que se sinta obrigado a falar justamente, $e$ de modo táo paradoxal ou aporético, 
tão impossivel, acerca de comunidade, direito, liberdade, igualdade [...]? (DERRIDA, 1994, p. 100).

Como ler discursos que contestam radicalmente os esquemas tradicionais da causalidade ou da significação, que remetem à irredutibilidade do que se mantém além desse discurso mesmo: o outro, o acontecimento, a singularidade?

No contexto de tais interrogaçóes, importa considerar uma situação excepcional e ao mesmo tempo exemplar, que solicita sobremaneira o estatuto, amplamente desconstruído em Derrida, da propriedade autoral: a impossível propriedade de uma língua, uma espécie de "alienação" originária que institui toda língua em língua do outro. Derrida é peremptório a respeito: em lugar de neutralizar as diferenças, o reconhecimento de uma des-(a)propriação da língua é da ordem de um afinamento crítico: ele permite identificar mais facilmente "[...] fantasmas, 'ideologias', 'fetichizações' e simbólicas da apropriação” (DERRIDA, 1996a, p. 121).

Ousadia assumida de nosso Autor: um discurso sobre a língua "expropriada” seria o único capaz de abrir para uma política, para um direito e para uma ética. Isto porque motivos que têm sua herança confirmada apenas em parte (a liberação, a emancipação, a revolução) alimentam uma estrutura de indecidibilidade pela qual as razões são analisadas à luz de sua possível e inevitável perversão. A perspectiva capacita a sugerir sui generis relação entre o poético e o político que seria relevante, em outras circunstâncias, analisar em detalhes. De fato, lê-se, em Monolinguisme de l'autre:

\footnotetext{
É no momento exato de escrever ou de ler, no exato momento da experiência poética que a decisão deve se elevar de um fundo de indecidibilidade. Essa é freqüentemente uma decisão política - e uma decisão do político. A condição indecidível de decisão como de responsabilidade inscreve a mentira no acaso, e o terror na ipseidade do hóspede. (DERRIDA, 1996a, p. 119).
}

O rastro de tal inscrição - que matiza com um sentimento de inevitabilidade os motivos da singularidade, da ipseidade, da responsabilidade e da hospitalidade - atravessa um imenso campo problemático, aquele da historicidade dos valores. A postulação de uma necessária perversão como fundamento do estar-para-vir (a-venir) leva a ponderar acerca das possibilidades do acontecimento do novo. Toda palavra é promessa de uma "língua ainda 
inaudita”. Contudo, a fatal precipitação de toda promessa força o que é outro a se reduzir ao mesmo. Nada está-para-vir, ressalta Derrida, sem herança e sem possibilidade de se repetir. Impossível é, pois, inventar uma língua suficientemente outra para não mais se deixar reapropriar pelos esquemas normativos (léxico, semântica, retórica, gramática) de toda língua dada. "A improvisação de alguma inaugurabilidade talvez seja o impossível mesmo. A reapropriação tem sempre lugar" (DERRIDA, 1996a, p. 125). Paradoxalmente, Derrida (1996b, p. 15) sustenta, em outro momento, a ausência de horizonte condiciona o próprio futuro. A aparição do acontecimento deve marcar todo horizonte com "brechas de expectativa".

Permanece, pois, uma promessa de verdade que reclama uma crença e uma confiança para além de toda prova. Porquanto a aporia da indecidibilidade, no caso da língua, mostra-se inevitável, ela engaja uma "linguagem impossível, ilegível, inaceitável". Permanece a convicção de que enfrentar o aporético é produzir acontecimentos na língua dada. Por vezes, ressalva Derrida (1996a, p.125), acontecimentos não constatáveis, ilegíveis. "Acontecimentos sempre prometidos mais que dados" ${ }^{3}$.

O gesto de invenção que deixa tais marcas no corpo da língua - falase aqui de "deformações", "transformaçôes", "expropriaçôes", "anomalias", “des-regulaçôes” (DERRIDA, 1996a, p. 124) -, por inúmeras vezes Derrida o qualifica de plural, seguindo o credo mesmo da desconstrução. Ora, não deixa de surpreender que em seus últimos textos os motivos da pluralidade ou da multiplicidade cedam espaço a um pensamento do único, da singularidade. "O singular inaugura sempre, ele chega mesmo, imprevisivelmente, como aquele que chega, através da repetição" (DERRIDA, 2000). Inesperada solicitação de uma exemplaridade que permite reinscrever junto ao corpo de uma singularidade insubstituível, para dá-la assim a remarcar, a estrutura universal de uma lei. Derrida indaga:

\footnotetext{
3 É possível repertoriar na massa argumentativa dos textos derridianos dos anos 1990-2000 os elementos conceituais e estilísticos que caracterizam o aporético como constitutivo de uma ética do acontecimento. Assim, retenha-se: em "Non pas l'utopie, l'im-possible" (Papier-machine), a impossibilidade como possibilidade da ética; em Politiques de l'amitié, a aporia do acontecimento trabalhada em termos de um "talvez" transcendental, junto a um repensar do político em sua totalidade histórica; em Apories, os motivos do inapropriável e do impossível à luz do pensamento heideggeriano da Ereignis; em Psyché. Inventions de l'autre, a noção desconstruída de invençẫo em sua dupla implicação de inaugurabilidade e iterabilidade; em Force de loi e em Papier-machine, a epoché da regra, a aporia do indecidível e a responsabilidade heterogênea ao saber; em Adieu à Emmanuel Lévinas, a lei da alteridade radical e a decisão ética reinventada a cada situação singular.
} 
O que se passa quando alguém descreve uma 'situação' pretensamente singular, a minha, por exemplo, descreve-a testemunhando em termos que o excedem, numa linguagem cuja generalidade adquire um valor de certo modo estrutural, universal, transcendental ou ontológico? (DERRIDA, 1996a, p. 40) .

É a experiência da linguagem que torna possível a articulação entre a universalidade transcendental ou ontológica e a singularidade exemplar ou testemunhante de uma existência. Pergunta-se ainda Derrida:

Como determinar um isso singular cuja unicidade justamente depende unicamente do testemunho, do fato que certos indivíduos, em certas situaçôes, atestam os traços de uma estrutura universal, revelam-na, indicam-na, dáo-na a ler mais vivamente, mais vivamente como se diz e porque se diz assim sobretudo de uma ferida, mais vivamente e melhor que outros [...]? (DERRIDA, 1996a, p. 40)4.

Nessa chave, Derrida fala de "martírio" e de "paixão", modo de introduzir um corpo, o corpo do filósofo, seus instintos e pulsóes; ainda, o corpo da língua e da escrita. $\mathrm{O}$ itinerário remete naturalmente às figuras da anamnese do Eu. Por diversas vezes, a existência-em-situação ganha na escrita derridiana traços de uma singularidade narcísica. Importa, porém, observar certo anacronismo do ecce homo de Derrida em face de acontecimentos (tais como Auschwtiz) regidos por uma lógica, uma economia, uma tópica que não mais dependem do ego e da consciência. É preciso, ainda, sublinhar - nessa franja do público e do privado, do dentro e do fora, do eu e do outro, onde evoluem os "argumentos" do acontecer - a evocação autorretratística de um "hiper-responsável irresponsável”, aquele mesmo que imagina o impossível como único possível, desejoso de nada responder diante de ninguém (DERRIDA, 2001).

\footnotetext{
4 Seria possível caracterizar uma contra-hermenêutica desconstrutivista (a priori, uma contradiçấo em termos) e o sentido crítico que ela reserva aos motivos da singularidade e da exemplaridade. Com o que identificar posiçôes argumentativas de base no trato derridiano com o acontecimento: a flutuação semântica em torno dos termos "novo", "vinda", "primeira vez"; os deslocamentos dos esquemas de causalidade e de significação nos temas ético-políticos; as estratégias "retóricas" de uma escrita do/no "talvez".
} 


\section{“COMO DIZER O ACONTECIMENTO?”}

Face ao que acima se reportou, ganha compreensível relevo a leitura ficcional do acontecimento. Outro do discurso regrado da filosofia, a literatura importa a Derrida na medida em que seu "gênio" dá lugar a acontecimentos que estấo "[...] longe de se inscrever na série, na seqüência homogênea ou na filiação contínua de uma gênese, de uma genealogia ou de um gênero" (DERRIDA, 2005, p. 72); em outros termos, na irredutibilidade de seu gênio a axiomas de fechamento ou de completude, a literatura se conforma "[...] no decurso de acontecimentos de corte absolutamente singulares, inaugurais, instituintes, sem passado e sem imitação possíveis" (DERRIDA, 2005, p. 79). Ao mostrar os modos como a ficção em sua incomensurabilidade, furta-se à "cláusula do gênero" - o conhecimento literário comporta uma "traição" da Literatura propriamente dita (DERRIDA, 2005, p. 73; 2003b, p. 265) -, é precisamente a noção de gênero que Derrida desconstrói paradigmaticamente. Com o que questionar pertenças, invariavelmente devidas a uma fobia taxonômica. Donde as interrogações que se nos impóem: como reconhecer as fronteiras, o funcionamento e os efeitos institucionais deste ou daquele gênero? como avaliar competências? como outorgar autoridade? Enfim: "Onde passa a linha de partilha entre o acontecimento de um enunciado inaugural, uma citação, uma paráfrase, um comentário, uma tradução, uma leitura, uma interpretação?” (DERRIDA, 2003b, p. 12).

No afã de um recorte de suficiente nitidez entre a segurança de toda filiação contínua a uma gênese, a uma genealogia ou a um gênero, e a descontinuidade do inteiramente outro, a literatura revela-se à leitura derridiana território de todas as contaminaçóes e de todas as indecisóes. Sua potência própria, afiança o autor de Genèses et généalogies..., consiste em “[...] retirar ou denegar o poder e o direito de decidir, de optar entre realidade e ficção, testemunho e invenção, concretude e imaginação, imaginação do acontecimento e acontecimento da imaginação" (DERRIDA, 2005, p. 50). Oni-potência-outra, isto é, capacidade de indistinção, a literatura incita à apreensão "não-genérica e não-genealógica" do outro como o que se passa, como o que acontece.

A literatura atrai Derrida em razão da evidência de seu "estatuto jurídico precário", isto é, de sua irredutibilidade a uma intencionalidade específica inscrita junto ao corpo social. $\mathrm{O}$ que em grande parte explica o direito incondicional da "literaridade" de tudo dizer: "[...] a mais selvagem das autonomias, a desobediência mesma”, em toda inocência (DERRIDA, 1998, 
p. 29-30). Ora, se a literatura joga inocentemente em perverter distinçóes - com que se compraz uma leitura desconstrutora ocupada em desrecalcar as escolhas feitas junto a sistemas dicotômicos -, Derrida retira particular proveito reflexivo do fato de a narrativa blanchotiana - sobretudo L'instant de ma mort, analisado exaustivamente em Demeure - dispor sobre um "limite indecidível" a partilha entre ficção e testemunho.

Esse limite é uma chance e uma ameaça, o recurso a um tempo do testemunho e da ficçáo literária, do direito e do não-direito, da verdade e da não-verdade, da veracidade e da mentira, da fidelidade e do perjúrio. (DERRIDA, 1998, p. 31) .

Vê-se, assim, a leitura do filósofo engajar uma reflexão sobre o direito da literatura de dispor (e de decidir acerca) das "virtualidades espectrais" e, por conseguinte, das mentiras, perjúrios e fragmentaçóes do verdadeiro que venham matizar todo testemunho real e responsável dos acontecimentos. Com o que estimar o valor argumentativo de um rebatimento da presumida "irresponsabilidade" da ficção sobre uma "justa referência à verdade"s.

Por sua forma, a literatura é estruturada de modo a "[...] guardar em reserva indecidível aquilo mesmo que ela confessa, mostra, manifesta, exibe, expóe à saciedade" (DERRIDA, 2005, p. 36-37). Ao refletir o testemunho não mais em relação ao conceito de ficção, mas a partir dele, Derrida dá a pensar uma filiação insuspeita, secreta, entre literatura e filosofia, uma partilha da "tentação analógica" - onde sustentar a afirmação e a negação contidas num "ser como". Ao alimentar a impossibilidade de decidir se o que se passou aconteceu na realidade, "[...] se este na realidade é ainda imanente à ficção, tal um tremor da sobrecarga ficcional, um efeito suplementar da ficção" (DERRIDA, 2005, p. 19), a literatura ensina à filosofia a devolver às palavras

\footnotetext{
5 É possível, por exemplo, avaliar em Demeure (1998) e em Parages (2003b) a eficácia da leitura derridiana do acontecimento ficcionalizado. Observar o modo como, ao desestabilizar a dicotomia entre ficção e testemunho, Derrida suscita questôes práticas, no sentido ético ou deontológico do termo: quais os direitos da ficçấo literária e do documento náo literário? quem autoriza quem a desvelar algo de secreto numa obra pública? A leitura literária do filósofo equivale à produção de um acontecimento no universo regrado do discurso filosófico. Derrida procura, pois, pelos efeitos de parasitagem entre ficção e testemunho denotados na narrativa blanchotiana. No registro estilístico, ele observa o uso dos modalizadores ("talvez", "antes", "como"), dos anacolutos ("eu sei - sei-o", "eu sei, eu imagino"), dos sintagmas do tipo "X sem X" e da lógica do neutro. De modo a arrematar a caracterizaçấo da leitura literária derridiana, tarefa a que nâo podemos nos ater, no presente texto, seria preciso elencar alguns de seus procedimentos mais recorrentes: o recorte constituinte, a empatia tradutora, a neologia conceitual, a inflação citacional, o recurso a uma indecidibilidade, a lógica da parasitagem entre dois opostos, a perturbação dos limites entre texto, paratexto e contexto.
} 
seu poder de especulação e de imaginação. Importa, pois, considerar os efeitos argumentativos de tal capacidade.

Nas leituras literárias de Derrida, empresa interpretativa motivada pela invenção que a ficção dispóe, o pensamento é deixado à sua guisa, ao sabor dos desvios e deslocamentos do gesto estilístico. Dir-se-ia que a escrita dá-se ali um espaço de vacância, de disponibilidade, pouco comprometida com as experiências da disciplina filosófica. As ficções de Blanchot são mesmo demonstrativas das virtudes de "uma escrita suspensa"; elas são literalmente "pontos de suspensão": suspendem os motivos ostensivamente filosóficos, postergam-nos ao mesmo tempo em que os liberam de sua canônica. Ao sabor dos itálicos, ressalta Derrida, que refletem visualmente a literatura:

Itálicos suspendem, em literatura, a realidade do que se diz aqui acontecer na realidade. Os itálicos levam a pensar, até a destacá-lo, no próprio corpo da questão: $\mathrm{O}$ que é a realidade? O que é um acontecimento? O que é um acontecimento passado? E o que quer dizer "passado" ou "passar-se", etc.? Tantas incertezas ou aporias [...] (DERRIDA, 2005, p. 21).

Por fim, Derrida encontra em Blanchot o tema da morte, o "acontecimento por excelência". A ficcionalização do "último instante" acentua, por assim dizer, a confrontação das óticas em torno do acontecimento. Em L'instant de ma mort, a literatura é "apóstrofe suspensiva" que fascina o filósofo, permitindo-lhe meditar o "encontro da morte como antecipaçáo com a própria morte". A "última vez" faz de um ponto de suspensão um ponto de encontro "[...] entre o que está para acontecer e o que acaba de acontecer, entre o que virá e o que acaba de advir, entre o que vai e vem. Mas como o mesmo. A um tempo virtual e real, real como virtual" (1998, p. 82). Dessa maneira, a narrativa do acontecimento último remete a filosofia à instância do que difere, como a différance, "[...] para além da identidade e da diferença" (DERRIDA, 2003b, p. 179). Confronta-a, pois, com a lei espectral do acontecimento: necessidade que excede a oposição entre o real e o irreal, o atual e o virtual, o efetivo e o fictício. Ao estruturar uma virtualidade que não mais se saberia opor à atualidade efetiva - estrutura constituinte que Derrida diz ser, ainda, uma "fratura desestruturante" -, a ficção literária permite um "testemunhar em verdade", uma "referência justa à verdade".

Estime-se aqui a audácia da perspectiva derridiana, a propósito de L'instant de ma mort, brevíssima narrativa blanchotiana que confia ao literário o testemunho do intraduzível acontecimento de espera pela iminente morte. 
A exigência de veracidade, de sinceridade ou de objetividade não se verifica desautorizada em face de uma "atestação impossível", aquela da "experiência não experimentada daquele que morre”. O filósofo-literato poderá mesmo sustentar, em Demeure, contrário à lógica filosófica ou especulativa donde se ausenta todo acontecer:

[...] é o acontecimento, portanto uma paixão - pois a experiência do que acontece deve ser paixão, exposição ao que não se vê vir e que não se saberia predizer, dominar, calcular ou programar -, é essa paixão, tal como é descrita no instante de minha morte, que conduz a filosofia e torna possível a lógica especulativa. (DERRIDA, 1998, p. 122).

A extrema audácia dessa passagem sintética justifica de per si os trabalhos de investigação aqui preconizados.

O testemunho veraz obsedado pelos jogos de enunciaçáo do ficcional - no que Derrida (1998, p. 94) chama "o lugar passional da escrita literária" - recorta diversamente a questão de uma partilha da língua, da corresponsabilidade da competência linguística, retórica, ou mesmo pragmática. Está-se aqui, admite Derrida, diante de um problema sem fundo, um problema "dramático", cujas dimensóes críticas, políticas e jurídicas cumpriria avaliar, ainda que o autor admita necessários "refinamentos infinitos". Isso porque, no acontecimento da morte, uma partilha da finitude parece motivo particularmente deslocado: seja pela "cumplicidade perturbadora entre a ficção e o testemunho", emblematizada pela narrativa blanchotiana, seja, sobretudo, porque as categorias assim inquietadas, fragilizadas, decompóem os conceitos clássicos da atestação e da autobiografia - no que ambas "[...] parecem excluir, de direito, a ficçâo e a arte, na medida em que é devida a verdade, toda a verdade, nada mais que a verdade" (DERRIDA, 1998, p. 51).

Preconize-se, pois, acompanhar Derrida nos "recondicionamentos" do testemunho autobiográfico: tomado nos moldes da escrita do desastre em Blanchot, ele "hospedaria" o outro (a morte mesma), à maneira de uma obra de arte, isto é, manifestaria a verdade concedendo ao leitor a responsabilidade de recebê-la através da mentira ou da ficção. Vê-se, pois, uma narrativa de bom senso, exigida por um conceito banal de testemunho, ceder terreno a um espaço de desconstrução literariamente conformado, onde o que Derrida chama a "loucura da língua" - sua capacidade de ser hóspede-refém (hôte, otage) do outro - permite, enfim, a experiência do impossivel. 
A literatura transpôe ficticiamente a dialética do impossível e do contingente mobilizada por toda relação com a morte. Uma relação impossível com a morte, o impossível tornado possível enquanto impossível: eis o que torna "insensata" a narrativa para o escritor; eis o que desafia a análise para o filósofo. Possível-impossível: dois modos não necessariamente antitéticos em Derrida de se reportar ao que é outro. A literatura, convocada a pontuar seus trânsitos e mutualidades, presta-se a "[...] confessar o inconfessável” (DERRIDA, 1998, p. 114), a saber: que a tarefa do saber é impossível no tocante ao acontecer. A aposta de uma literatura apreendida pela filosofia é uma aposta do impossível, ou melhor, do "im-possível”, porque ela faz "[...] a experiência dessa impossibilidade" que se anuncia "intraduzivelmente diferente" (DERRIDA, 1998, p. 120).

Evidencia-se, aqui, a referência à expressão heideggeriana da morte como "possibilidade de uma impossibilidade", expressão sobre a qual Derrida tanto indaga em Apories: "como pensá-la? como dizê-la no respeito da lógica do sentido? como abordar, viver, existir isso? como dela dar testemunho?" (DERRIDA, 1996c, p. 121). Se intrincada argumentação filosófica leva-o a "[...] medir todas as explosóes em cadeia que ela mantém em reserva no subterrâneo da analítica existencial”, se ele procura esclarecê-la à luz de uma lógica da aporia, importaria observar complementarmente como o leitor derridiano de Blanchot vê tal possibilidade de uma impossibilidade virtualizada nas narrativas mais anômicas. Tal leitura retiraria quiçá sua virtude maior do enfrentamento, propiciado pelo motivo, entre os dois registros da intervenção derridiana : a teoria e a leitura/escrita.

Poder-se-ia, por fim, pelo que acima se sugeriu, preconizar uma avaliação do alcance crítico do discurso de desconstrução enquanto jogo diferencial de duas discursividades heterogêneas: a Filosofia e a Literatura. No rastro da desconstrução das noções de "gênero" e de "disciplina", seriam evidenciadas as solicitaçóes do conceitual por parte do ficcional; consequentemente, a "plasticidade figural" que caracteriza as leituras literárias derridianas (MALABOU, 2005). Além disso, tornar-se-iam analisáveis as injunçóes da escritura filosófica do literário junto ao projeto virtual e real, espectral, portanto, de um "porvir mais justo" da língua e do pensamento.

No fim das contas, uma ética do acontecimento, aporética porque impeditiva de toda autoridade que o submeta à forma de sua inquisição, convoca o texto literário precisamente em razão de sua capacidade de evidenciar para o pensamento desconstrutor potências discursivas. E se se 
observar, como o faz Artous-Bouvet (2006), que a desconstrução não é senão a totalidade articulada das operaçóes que produz, cumpriria então salientar que a literatura constitui em tal operacionalidade um "máximo desconstrutor". Mesmo porque o discurso literário, assinala Derrida (1972, p. 93), seria o "[...] menos comprometido pelos modelos, as regras, os gêneros e outras instâncias atreladas às funções de fechamento". Tal caracterização permitiria assim entender a singularidade dos gestos de leitura de Derrida, onde os textos parecem irremediavelmente comprometidos com as coordenadas estratégicas que vimos aqui serem próprias ao pensamento ético-político. Singularidade dos gestos, operacionalidade dos textos. Com o que avaliar a força e a coerência, enfim a unidade teórica do significante - ou unidade-de-nome "desconstrução", nome que se recusa enquanto tal.

FONTES FILHO, Osvaldo. An "impossible possibility of saying": the event in philosophy and literature, according to Jacques Derrida. Trans/Form/Ação, Marília, v. 35, n. 2, p. 143162, Maio/Ago., 2012.

\begin{abstract}
This paper takes account of the "impossible possibility of saying the event", a fertile notion in Derrida's last writings. The "possibility of the impossible" is an expression borrowed from Heidegger's concept of Ereignis. It is related to an aporetic ethics concerned about responsibility in facing the "inappropriability of events." In some of Derrida's most famous possible-impossible aporias - justice rebellious to rule, the "ghost of the undecidable" in every event of decision, invention that always presupposes some illegality - an ethics of alterity puts forward a critique of the unitary self, a subjectivity under the underivable interpellation coming from events. The relevance of the otherness to understanding any decision solicits "the law of the singular event", a promise of originality. However, the "incalculable uniqueness and exceptionality" of each event implies for Derrida a promise of a monolingual community, with its suspending or bracketing of dissemination acts. In the face of the "reserves of the undecidable" of fiction, that promise of uniqueness seems obviously impossible. This article aims, therefore, to estimate the deconstructive fertility of the relationship between testimony and fiction in literature, a moment in Derrida's thought in which the categories of truth break down, thus revealing literature as the "other" of philosophy.
\end{abstract}

KEYWORDS: Event. Philosophy. Literature. Singularity. Alterity. Testimony. Truth. 


\section{REFERÊNCIAS}

ARTOUS-BOUVET, Guillaume. L'Autre Texte : Derrida lecteur du littéraire. In: Les philosophes lecteurs. Fabula (Littérature, histoire, théorie), n 1 , fevereiro 2006. Disponível em: <http://www.fabula.org/lht/1/Artous-Bouvet.html>. Acesso em: 20 nov. 2011.

BLANCHOT, Maurice. L'Instant de ma mort. Paris: Gallimard, 2002.

BORRADORI, Giovanna. Le concept du 11 septembre : Dialogues à New York (octobredécembre 2001) avec Giovanna Borradori. Grenoble: Editions Galilée, 2004.

DERRIDA, Jacques. Une certaine possibilité impossible. Dire l'événement, est-ce possible? Séminaire de Montréal. Paris: L’Harmattan, 2001.

. Auto-immunités, suicides réels ou symboliques. In: BORRADORI, Giovanna. Le Concept du 11 septembre, 2004a, p.133-197.

. Derrida, penseur de l'événement (entretien avec Jérôme-Alexandre Niesberg). L'Humanité, Paris, 28 janvier 2004b. . Politiques de l'amitié. Paris: Galilée, 1994. . Le monolinguisme de l'autre, ou la prothèse d origine. Paris: Galilée, 1996a. . Foi et savoir. La Religion, sous la direction de Jacques Derrida et Gianni Vattimo, Paris: Seuil, 1996b. . Apories - Mourir s’attendre aux "limites de la véritê". Paris: Galilée, 1996c. . Gêneses, genealogias, gêneros e o gênio. Porto Alegre: Sulina, 2005. . Demeure. Maurice Blanchot. Paris: Galilée, 1998.

.Voyous. Paris: Galilée, 2003a.

. Parages. Paris: Galilée, 2003b.

.Positions, Paris: Éditions de Minuit, 1972.

. De l'économie restreinte à l'économie générale. Un hégélianisme sans reserve. L'écriture et la différence. Paris: Éditions du Seuil, p. 369-407, 1967.

. Autrui est secret parce qu'il est autre. Le monde de l'éducation, $\mathrm{n}^{\circ} 284$, setembro 2000. Disponível em: <http://www.jacquesderrida.com.ar/frances/autri.htm>. Acesso em: 18 nov. 2011.

MALABOU, Catherine. La Plasticité au soir de l'écriture. Dialectique, destruction, déconstruction. Paris: Éditions Léo Scheer, 2005.

TOUDOIRE-SURLAPIERRE, Frédérique. Derrida, Blanchot, Peut-être l'extase . Les philosophes lecteurs, Fabula (Littérature, histoire, théorie), n¹, 2006. Disponível em $<$ http://www.fabula.org/ht/1/Toudoire-Surlapierre.html>. Acesso em: 20 nov. 2011. 


\section{Bibliografia DE APOIO}

BLANCHOT, Maurice. La littérature et le droit à la mort. La Part du feu. Paris: Gallimard, 1987, p. 293-331.

CLARK, Timothy. Derrida, Heidegger, Blanchot. Cambridge (N. Y.): Cambridge Univ. Press, 1992.

DUQUE-ESTRADA, Paulo C. (Org.). Derrida e a escritura. Às margens: a propósito de Derrida. Rio de Janeiro: Ed. da PUC, p. 9-28, 2002.

GUIMARÁES, Rodrigo. Diálogos entre a literatura contemporânea e o pensamento de Jacques Derrida. Revista de Letras, São Paulo, v. 48, n. 1, p. 65-84, 2008.

HARTMAN, Geoffrey H. Saving the Text: Literature/Derrida/Philosophy. Baltimore: The John Hopkins University Press, 1981.

NASCIMENTO, Evando. Derrida e a literatura: notas de literatura e filosofia nos textos de desconstrução. Niterói: Ed. UFF, 1999.

SISCAR, Marcos. Jacques Derrida. Rhétorique et philosophie. Paris: L'Harmattan, 1998.

Recebido em: 04.01.2012

Aceito em: 23.01.2012 